\title{
Fuel Volatility Effects on Pool Fires in Compartments with Low Ventilation
}

\author{
OMAR ALJUMAIAH, GORDON ANDREWS, A. JIMENEZ, N.R. DUHOON AND HERODOTOS \\ PHYLAKTOU \\ Energy Research Institute \\ University of Leeds
}

Leeds, LS2 9JT, UK

\begin{abstract}
Pool fires in low ventilation compartments give rise to ghosting flames and their toxic and particulate emissions were investigated for $400 \mathrm{~mm}$ square pool fires in a $1.6 \mathrm{~m}^{3}$ compartment with ventilation of 0.035 $\mathrm{kg} / \mathrm{m}^{2} \mathrm{~s}$, air mass flow rate per pool surface area. These conditions produced global compartment equivalence ratios that were rich and this did occur for kerosene and heptane, but diesel and toluene only achieved near stoichiometric conditions. The low ventilation produced low ceiling temperatures of between 380 and $480^{\circ} \mathrm{C}$ with the highest temperature for diesel and the lowest for heptane. Particulate mass emissions were highest for kerosene at $6.5 \mathrm{~g} / \mathrm{kg}_{\mathrm{f}}$ and lowest for heptane at $0.9 \mathrm{~g} / \mathrm{kg}_{\mathrm{f}}$. Soot emissions were lowest for heptane at $0.2 \mathrm{~g} / \mathrm{kg}_{\mathrm{f}}$ and highest for kerosene at $5 \mathrm{~g} / \mathrm{kg}_{\mathrm{f}}$. These are relatively low soot emissions, due to the low fire temperatures for near stoichiometric combustion. These low temperatures were mainly due to low combustion efficiencies with high $\mathrm{CO}$ and $\mathrm{HC}$ yields.
\end{abstract}

KEYWORDS: Pool Fires, Compartment Fires, Fire Toxicity, Smoke, Ghosting Flames.

\section{NOMENCLATURE}

$A_{p} \quad$ Pool fire surface area $\left(\mathrm{m}^{2}\right)$

$A_{v} \quad$ Compartment air inlet area $\left(\mathrm{m}^{2}\right)$

$A / F \quad$ Mass ratio of air and fuel flow

$\mathrm{ACH}$ Air Changes per Hour

CO Carbon Monoxide

$\mathrm{CO}_{2}$ Carbon Dioxide

$c_{p} \quad$ Specific heat

CV Calorific Value (MJ/kg)

$C_{P} \quad$ Concentration of particulate mass $\left(\mathrm{g} / \mathrm{m}^{3}\right)$

$C_{g} \quad$ Concentration of gas, $\mathrm{v} / \mathrm{v}$

FID Flame Ionisation Detector

$H / C \quad H y d r o g e n$ to carbon molar ratio

$H R R$ Heat Release Rate, $\left(\mathrm{MJ} / \mathrm{kg}_{\mathrm{f}}\right)$

LHV Latent Heat of Vaporisation $\left(\mathrm{kJ} / \mathrm{kg}_{\mathrm{f}}\right)$

$M \quad$ Molecular weight ratio of pollutant/exhaust
MLR Mass Loss Rate, $\left(\mathrm{Kg}_{\mathrm{f}} / \mathrm{s}\right)$

NDIR Non-dispersive infra-red

NOx Nitrogen Oxides

UHC Total unburned hydrocarbons

$Y \quad$ Yield, $\left(\mathrm{kg}_{\mathrm{p}} / \mathrm{kg}_{\mathrm{f}}\right)$

Greek

$\eta_{\mathrm{c}} \quad$ Combustion Efficiency, Eq.3.

$\varnothing \quad$ Global Fire Equivalence Ratio

Subscripts

$\begin{array}{ll}a & \text { Air } \\ f & \text { Fuel } \\ g & \text { Gaseous pollutant } \\ P M & \text { Particulate Matter }\end{array}$

$P M$
Air

Particulate Matter 


\section{INTRODUCTION}

Hydrocarbon Pool fires are a common petrochemical fire hazard [1,2], but most work in this area is for freely ventilated pool fires such as the study by Chartris et al. [3]. For pool fires in a compartment with an open door and relatively high ventilation, fire temperatures can be in excess of $1000^{\circ} \mathrm{C}$ with associated high soot emissions [2]. For well ventilated compartment fires Ko et al. [4] and Bundy et al. [5] used a small scale compartment of $1.4 \mathrm{~m}^{3}$ which was very similar in size to that of the present work $\left(1.6 \mathrm{~m}^{3}\right)$. Gottuck et al. [6] have used a $2.2 \mathrm{~m}^{3}$ compartment to investigate ventilation controlled heptane pool fires. The present $1.6 \mathrm{~m}^{3}$ compartment has been previously used by Andrews et al. [7-9] to study air starved kerosene pool fires with 200mm square pools. Bundy et al. [5] and Gottuck et al. [6] used relatively large ventilation openings and generated rich mixtures with high yields of $\mathrm{CO}$ for heptane pool fires, similar to the findings of Chamberlain [2] and Ko et al. [4]. Apart from the work of the present authors [7-9] and the more recent work of Utiskul et al. [1] in a $0.064 \mathrm{~m}^{3}$ compartment' the behaviour of pool fires with very restricted ventilation has had limited study In this work a closed compartment was used with a constant air leakage that was equivalent to the air flow through the gaps around doors and windows [10].

Ko et al. [4], Bundy et al. [5] and Gottuck et al. [6] have shown, for well ventilated compartments of about $2 \mathrm{~m}^{3}$, that heptane and toluene pool fires generate rich global fire equivalence ratios with $\mathrm{CO}$ and soot yields of $>0.1$ for most of the rich pool fires investigated, where peak fire temperatures were in excess of $1000^{\circ} \mathrm{C}$. This is in agreement with the work of Chamberlain [2] even though the test rigs were much smaller, $2 \mathrm{~m}^{3}$ compared with $96 \mathrm{~m}^{3}$ [2]. These results show that high pool fire temperatures can be achieved in reduced scale compartments if there is sufficient ventilation. This is because it is well known that compartment fire temperatures and HRR are controlled by the compartment ventilation, as shown for pool fires by Chamberlain [2] and Andrews et al. [8]. Kerosene pool fire maximum HRR were 0.4 and $2 \mathrm{MW} / \mathrm{m}^{2}$ of pool area in the low ventilation $1.6 \mathrm{~m}^{3}$ compartment of Andrews et al. [7-9], $5.4 \mathrm{MW} / \mathrm{m}^{2}$ in the highly ventilated $1.4 \mathrm{~m}^{3}$ compartment of Bundy et al. [5] and $0.8-1.8 \mathrm{MW} / \mathrm{m}^{2}$ in the large scale well ventilated diesel pool fires of Chamberlain [2]. This shows the relevance for large scale pool fires of the use of a small scale $1.6 \mathrm{~m}^{3}$ fire compartment for studying pool fires in the present work.

Well ventilated compartment pool fires have flames attached to the pool, as occurs in freely ventilated pool fires [3]. In contrast, in low ventilation compartments pool fires give rise to ghosting flames [1]. Ghosting flames are flames detached from the surface of the pool that travel towards the oxygen rich areas and sometimes stabilize near the ventilation vents. Sugawa [11] first reported ghosting flames in his work on poor ventilation compartment fires. Then Gottuk et al. [6] reported similar phenomena in their work where hexane pool fires were burned in a compartment with relatively high ventilation and they reported stabilized flames near the exhaust window. More recently, Utiskul et al. [1] conducted a study on small pool fires in an enclosure. The ghosting flame regime was identified graphically on a plot of the fuel mass loss rate per pool surface area, $\mathrm{g}_{\mathrm{f}} / \mathrm{m}^{2} \mathrm{~s}$, to a ventilation parameter of air mass flow rate per pool surface area, $\mathrm{g}_{\mathrm{a}} / \mathrm{m}^{2} \mathrm{~s}$ [1] Ghosting flames for heptane occurred for fuel mass loss rates from $5-30 \mathrm{~g}_{\mathrm{f}} / \mathrm{m}^{2} \mathrm{~s}$ and air ventilation rates from $120-1000 \mathrm{~g}_{\mathrm{a}} / \mathrm{m}^{2} \mathrm{~s}$. The global A/F was between 24 and 33/1, which was a $\varnothing$ of 0.63 - 0.45. The fuel mass loss rate decreased as the pool area increased at air rates below $400 \mathrm{~g}_{\mathrm{f}} / \mathrm{m}^{2} \mathrm{~s}$. For free flames the burning rate was $12 \mathrm{~g}_{\mathrm{f}} /\left(\mathrm{m}^{2} \mathrm{~s}\right)$, but at ventilation rates higher than $400 \mathrm{~g}_{\mathrm{f}} / \mathrm{m}^{2} \mathrm{~s}$ the burning rate was higher than for free flames due to the high compartment temperature with large fuel vaporization rates.

In the $96 \mathrm{~m}^{3}$ compartment of Chamberlain [2] the fuel mass loss rate for the two ventilations studied with diesel fuel were $19-26 \mathrm{~g}_{\mathrm{f}} / \mathrm{m}^{2} \mathrm{~s}$ and no ghosting flames were reported, but the peak fire temperature was much higher than in the work of Utiskul et al. [1]. In the highly ventilated small scale fire of Bundy et al. [5] peak fire temperatures for heptane and toluene pool fires were $1150^{\circ} \mathrm{C}$, similar that that of Chamberlain [2]. Their work had fuel mass burn rates of $151 \mathrm{~g}_{\mathrm{f}} / \mathrm{m}^{2} \mathrm{~s}$ for heptane and $186 \mathrm{~g}_{\mathrm{f}} / \mathrm{m}^{2} \mathrm{~s}$ for toluene. This indicates that the occurrence of ghosting flames is associated with low fire temperatures, which are produced by low ventilation rates. For freely ventilated diesel pool fires of $4 \mathrm{~m}$ diameter Chatris et al. [3] found the mass burn rate was $55 \mathrm{~g}_{\mathrm{f} / \mathrm{m}}{ }^{2} \mathrm{~s}$. The work of Chamberlain [2] shows that for diesel pool fires reduced ventilation reduced the mass burn rate. This was also found by Utiskul et al. [1] for heptane.

Andrews et al. [7-9] introduced a compartment fire ventilation parameter $K_{\text {in }}$ that is the air total open area, $\mathrm{A}_{\mathrm{v}}$, divided by the cross sectional area of a cubic room of equivalent volume $(\mathrm{V})$ to the test room. For a typical $3 \times 5 \times 3 \mathrm{~m}$ room with volume of $45 \mathrm{~m}^{3}$ a typical door size is $2 \times 1 \mathrm{~m}$ with air gaps from $0.2-2 \mathrm{~mm}$ [10] and this gives a $\mathrm{K}_{\mathrm{in}}$ range from $0.1-1 \%$. For $\mathrm{K}_{\mathrm{in}}$ greater than this, a door or window would have to be 
partially open. Andrews et al.[7-9] studied $\mathrm{K}_{\text {in }}$ of $0,0.1 \%$ and $1 \%$ in the same equipment as in the present work and for $200 \mathrm{~mm}$ square diesel pool fires showed that in the steady state burning phase of the fires, the induced ventilation rate was 19 and 81 air changes per hour $(\mathrm{ACH})$ for the 0.1 and $1 \% \mathrm{~K}_{\text {in }}$ respectively. As pool fires in ventilation restricted compartments burn at steady state, with a constant air entrainment, the present work was carried out at a fixed ventilation rate with the compartment air flow externally controlled to give $10.6 \mathrm{ACH}$, which is equivalence to a closed door with high air leakage. The lowest value of $\mathrm{K}_{\mathrm{in}}$ that has been studied prior to this work was $1.32 \%$ in the work of Sugawa et al. [11], 1.7\% by Peatross and Beyler [12] and $1.9 \%$ by Audouin et al. [13]. All of these investigators used pool fires as the fire load and all found ghosting flames occurred. In larger pool fire ventilation studies: Wieczorek [14] used $\mathrm{K}_{\mathrm{in}}$ of 3.5 and $6.9 \%$, Chamberlain [2] used 7.5 and $21 \%$ and Bundy et al. [5] used $\mathrm{K}_{\mathrm{in}}$ of $31 \%$. Fuel mass burn rates increased with $\mathrm{K}_{\mathrm{in}}$. No occurrence of ghosting flames was reported in these higher ventilation pool fire studies. Cheung et al. [15] have modeled fires in rooms with air gaps around the door varied from 3 to $10 \mathrm{~mm}$. Their geometry gives $\mathrm{K}_{\text {in }}$ from $0.24 \%$ to $0.8 \%$, which is similar to the range of Andrews et al. [7-9]. However, they imposed a fire HRR in the model and computed the spread of smoke through the door gap; they did not compute the HRR based on the air leakage through the door gap, which has been done for the present kerosene results by Aljumaiah [16] using FDS modelling.

In the present work pool fires $400 \mathrm{~mm}$ square were investigated with ventilation restricted to 10.6 air changes per hour or $35 \mathrm{~g}_{\mathrm{a}} / \mathrm{m}^{2} \mathrm{~s}$ air mass flow rate per pool surface area. This is much lower than the 250$1050 \mathrm{~g}_{\mathrm{a}} / \mathrm{m}^{2}$ s pool surface area ventilation rate used in the $200 \mathrm{~mm}$ square kerosene pool fires [7-9], where ghosting flames were not observed. The $35 \mathrm{~g}_{\mathrm{a}} / \mathrm{m}^{2} \mathrm{~s}$ ventilation was below the ghosting flame range of Utiskul et al. [1] of $120-1000 \mathrm{~g}_{\mathrm{a}} / \mathrm{m}^{2}$ s for heptane and was in their self-extinction regime. The phenomenon of ghosting flames was investigated in this work for four different types of hydrocarbon fuels, each with a different fuel volatility, at $35 \mathrm{~g}_{\mathrm{a}} /\left(\mathrm{m}^{2} \mathrm{~s}\right)$. This air flow rate was chosen as it was close to the minimum that would sustain a flame. Lower ventilation rates with the $400 \mathrm{~mm}$ square pools would extinguish the flame due to self inerting with fuel vapour.

\section{EXPERIMENTAL TECHNIQUES}

A $1.6 \mathrm{~m}^{3}$ enclosed fire test facility, $1.4 \mathrm{~m} \times 0.96 \mathrm{~m} \times 1.25 \mathrm{~m}$, was used, as shown in Fig. 1, with separated entrained air inlet at floor level and fire product exit at ceiling level [7-9]. This compartment size is very similar to the NIST $1.4 \mathrm{~m}^{3}$ compartment used by Bundy et al. [5] to study pool fires and other fire types. The compartment was fitted with a high temperature $\left(500^{\circ} \mathrm{C}\right)$ glass window for the entire area of the front of the compartment. This was also fitted with an insulated cover door to stop radiative heat losses from the fire. 400mm square pool fires of kerosene, diesel, heptane, and toluene were investigated. The initial pool fuel mass was $2.4 \mathrm{~kg}(\sim 103 \mathrm{MJ})$, which gave a depth of $20 \mathrm{~mm}$ in the $40 \mathrm{~mm}$ deep $400 \mathrm{~mm}$ square pan. The fuel mass consumption was derived from the oxygen consumption HRR and the combustion efficiency, as discussed later. The pool fire was ignited using a butane gas torch, briefly applied to the surface of the pool until a continuous flame was established, and then the compartment door was closed.

The properties of the four liquid fuels used are summarized in Table 1. Most previous work on pool fires in compartments, apart from the work of Chamberlain [2] and Chartris et al. [3], has used pure hydrocarbons that are very volatile, such as heptane or hexane or toluene $[1,4-6]$. In this work two pure hydrocarbon pool fires, heptane and toluene, were compared with the more common fuels kerosene and diesel. Volatility is the main difference in the fuels as combustion stoichiometry was very similar, at close to $14.6 \mathrm{~A} / \mathrm{F}$.

The forced ventilation air was metered using a thermal mass flow meter and fed through a plenum chamber under the fire enclosure floor, with air admission to the fire chamber through four long slots on the floor at the base of each wall. The four pool fire fuels were compared at 10.6 air changes an hour, which in the present compartment was an air flow rate of $20 \mathrm{~kg} / \mathrm{hour}(0.0056 \mathrm{~kg} / \mathrm{s})$ and this gave a ventilation rate per surface area of the pool of $0.035 \mathrm{~kg}_{\mathrm{a}} / \mathrm{sm}^{2} \mathrm{~s}$. This ventilation rate corresponded to a $\mathrm{K}_{\mathrm{in}}$ of approximately $0.04 \%$, by calibration of the air flow in fires with varied $\mathrm{K}_{\mathrm{in}}$. This air flow was in a region that Utiskil et al. [1] found was self-extinguishing for heptane, but was a regime of continuous combustion in the present work with a much larger pool size than the $190 \mathrm{~mm}$ diameter maximum pool size of Utiskul et al. [1].

The fire product gases flowed across the ceiling and exited through four slots around the periphery of the ceiling and then along the rear of the ceiling to an exit of $162 \mathrm{~mm}$ diameter in the centre of the compartment roof. The gases were well mixed at this point and were taken as representative of the fire ceiling product gases. Heated gas sampling lines at $190^{\circ} \mathrm{C}$ were used from the discharge duct, prior to any dilution with 


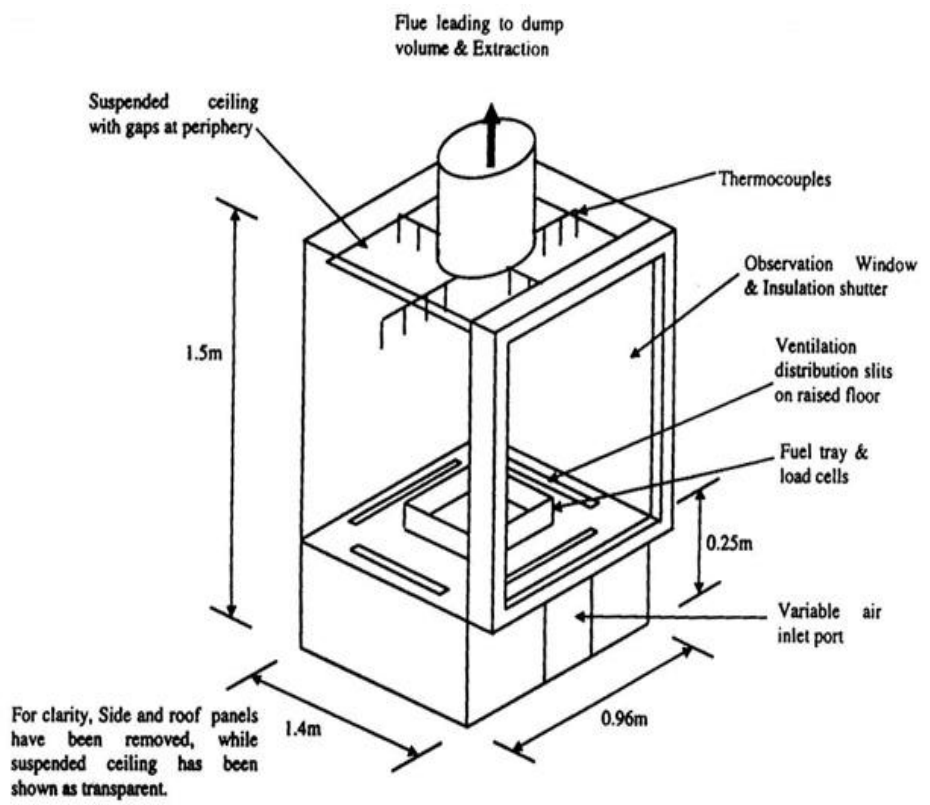

Fig. 1. The fire compartment.

Table 1 Properties of the four fuels used in the pool fires

\begin{tabular}{|c|c|c|c|c|c|c|c|c|c|}
\hline & $\mathrm{H} / \mathrm{C}$ & $\begin{array}{c}\text { Stoichio } \\
\text { metric } \\
\mathrm{A} / \mathrm{F} \\
\varnothing=1\end{array}$ & $\begin{array}{c}\text { Boiling } \\
\text { Temp. }{ }^{\circ} \mathrm{C}\end{array}$ & $\begin{array}{c}\text { Flash } \\
\text { Point } \\
\mathrm{C}\end{array}$ & $\begin{array}{c}\text { Lower } \\
\mathrm{FL} \%\end{array}$ & $\begin{array}{c}\text { Higher } \\
\text { FL \% }\end{array}$ & $\begin{array}{c}\text { LHV } \\
\mathrm{kJ} / \mathrm{kg}\end{array}$ & $\begin{array}{c}\text { CV } \\
\mathrm{MJ} / \mathrm{kg}\end{array}$ & $\begin{array}{c}\text { Specific } \\
\text { Heat } \\
\text { Capacity } \\
\mathrm{KJ} / \mathrm{kg} . \mathrm{K}\end{array}$ \\
\hline Heptane & 2.29 & 15.2 & 98 & -4 & 1 & 6.7 & 317 & 44.6 & 2.20 \\
\hline Toluene & 1.14 & 13.5 & 110 & 4 & 1.27 & 7.1 & 360 & 40.5 & 1.67 \\
\hline Kerosene & 1.92 & 14.7 & $150-260$ & 46 & 0.7 & 6 & 256 & 43.1 & 1.99 \\
\hline Diesel & 1.88 & 14.6 & $160-360$ & 52 & 0.4 & 1.7 & 228 & 43.2 & 1.88 \\
\hline
\end{tabular}

ambient air. The A/F and equivalence ratio, $\varnothing$, was calculated by carbon balance [17] from this gas sample and was the global fire $\emptyset$. One heated line was fed via a heated filter and pump to a gaseous emissions analysis system with heated flame ionization detector (FID) for total hydrocarbons, heated chemiluminescence NOx analyser and through a $2{ }^{\circ} \mathrm{C}$ refrigerated condenser to NDIR analysers for $\mathrm{CO}$ and $\mathrm{CO}_{2}$ and a paramagnetic analyser for oxygen. A second heated gas sample line took an exhaust sample to a heated filter paper particulate sampler. The sample was thermally cooled to $70^{\circ} \mathrm{C}$ in an oven, so that unburned fuel could condense onto the particulate matter, but water vapor would not. The filter paper housing had a $25 \mathrm{~mm}$ diameter soot collection area and was separately heated to $70^{\circ} \mathrm{C}$ to avoid water condensation. The Whatman GF/F filter was weighed to $10 \mu \mathrm{g}$ resolution before and after the test and the mass collected was divided by the total sample volume to yield the particulate mass concentration $C_{P}, g / \mathrm{m}^{3}$, which was converted, using Eq. 1, to a particulate yield using the A/F by mass determined by carbon balance from the gas analysis.

$\mathrm{Y}_{\mathrm{PM}}=\left[\mathrm{C}_{\mathrm{P}} / 1.18\right][1+\mathrm{A} / \mathrm{F}] \mathrm{g}_{\mathrm{PM}} / \mathrm{kg}_{\mathrm{f}}$

The density of the exhaust gases in the sample can be taken as that of air to better than $1 \%$ accuracy for hydrocarbon type combustion products. In this work this density was $1.18 \mathrm{~kg} / \mathrm{m}^{3}$ at the pressure and temperature of the sample gas flow meter.

The yields, $\mathrm{Y}_{\mathrm{g}}$, of $\mathrm{CO}$ and total unburned hydrocarbons, UHC, are given by Eq. 2. The measured volumetric concentration is $\mathrm{C}_{\mathrm{g}}$. The constant $\mathrm{M}$ is the molecular weight ratio of the toxic species to that of the exhaust sample gases, which are take to be air, which is accurate for hydrocarbon combustion to $<1 \%$ 
error. $\mathrm{M}$ is 0.991 for $\mathrm{CO}$ and 0.555 for $\mathrm{UHC}$, taken as $\mathrm{CH}_{4}$ equivalent, as the FID measures total UHC as $\mathrm{C}_{1}$ equivalent.

$\mathrm{Y}=\mathrm{C}_{\mathrm{g}} \mathrm{M}(1+\mathrm{A} / \mathrm{F}) \mathrm{kg} / \mathrm{kg}_{\mathrm{f}}$

The combustion inefficiency was determined from the energy content in the unburned CO and UHC, as in Eq. 3.

$1-\eta c=\left(\mathrm{Y}_{\mathrm{CO}} \times \mathrm{CV}_{\mathrm{CO}} / \mathrm{CV}_{\text {fuel }}\right)+\left(\mathrm{Y}_{\mathrm{CH} 4}\right)+\left(\mathrm{Y}_{\text {Soot }} \times \mathrm{CV}_{\text {Carbon }} / \mathrm{CV}_{\text {fuel }}\right)$

Here, CV is the calorific value of the unburned CO or UHC or soot. The CV of unburned fuel was taken as the same as the fuel. The soot term in the present work will be shown to be low and for the highest soot emitting pool fire was less than $2 \%$ of the fuel, which is relatively low compared to well ventilated pool fires in compartments $[2,5]$ and it is not very significant in the combustion efficiency calculations here, but is significant when the soot yield is $>>2 \%$.

To measure high levels of hydrocarbons in raw fire product gases it is essential that the gas sample handling system is heated. This includes the sample line, the sample particulate filter and pump and the connecting line to the FID. A partially heated sample system was used by Bundy et al. [5] where only the sample line to the water removal equipment was heated and the sample line to the FID was cold. This leads to considerable underestimation of the UHC in their work and hence to an underestimation of the fire combustion efficiencies. The sample continued to be heated inside the FID all the way to the sample feed into the $\mathrm{H}_{2} / \mathrm{He}$ gas flame. This ensures that no sample unburned vapour loss could occur. This type of heated sampling system has rarely been used in fire toxicity research and measurements of total hydrocarbons are rarely reported. The raw sample was taken before any possible secondary combustion could take place, so that the toxicity levels in the room of fire origin were measured. These would be the levels of fire toxic gases that would leak from a room with this type of fire to be diluted as they spread around a building.

Other methods of determining fire toxicity have some form of dilution of the product gases so that heated gas sampling systems are not required. The cone calorimeter dilutes the sample for freely ventilated fire specimens by of the order of 70:1 and with restricted ventilation to the fire compartment the dilution of the fire products is of the order of 300:1 [18]. In the Purser furnace method [18] under conditions where rich furnace combustion occurs, there is dilution of the products by 25:1 using by-pass air. High dilution lowers the dew point of the sample as well as cools the sample and water vapour does not condense. However, the dilution process may oxidise some of the product gases and not just dilute. There is only one reliable way to measure toxicity produced in experimental fires and that is to sample the raw fire product gases and this requires fully heated gas sampling systems, as used in the present work.

\section{RESULTS}

\section{Heat Release Rate}

The HRR was computed from the oxygen mass consumption. This was based on the metered mass flow of air into the compartment less the oxygen mass flow in the exhaust, calculated from the oxygen mass concentration in the exhaust times the exhaust mass flow rate, which was the air plus the fuel total mass flow. The oxygen in the exhaust was measured on a dry gas basis and was first converted into a wet basis. The removal of the water from the oxygen sample line after the $2^{\circ} \mathrm{C}$ gas sample condenser increased the concentration of oxygen by removing the water content, which was about $15 \%$ of the hot gas sample. The water vapour was calculated from the measured A/F.

The oxygen consumption HRR is shown in Fig. 2 as a function of time for the four pool fires. This shows that all four pool fires had a similar peak HRR in the range $16-18 \mathrm{~kW}$ or $100-112 \mathrm{~kW} / \mathrm{m}^{2}$. This is that expected from the constant flow, as there is typically $3 \mathrm{MJ} / \mathrm{kg}$ of air released in combustion [19], irrespective of the fuel and for $0.0056 \mathrm{~kg} / \mathrm{s}$ of air supply to the compartment $17 \mathrm{~kW}$ HRR would be expected, which is in agreement with that found. These pool fire HRR are very low in this severely air starved region. In the work of Utiskul et al. [1] using a CV of $43 \mathrm{MJ} / \mathrm{kg}$ for heptane, their fuel mass loss rate, which is not the same as the consumption rate due to the combustion inefficiency, the HRR would be in the range $0.17-1.3 \mathrm{MW} / \mathrm{m}^{2}$, much higher than in the present work. For the same air ventilation rate of 


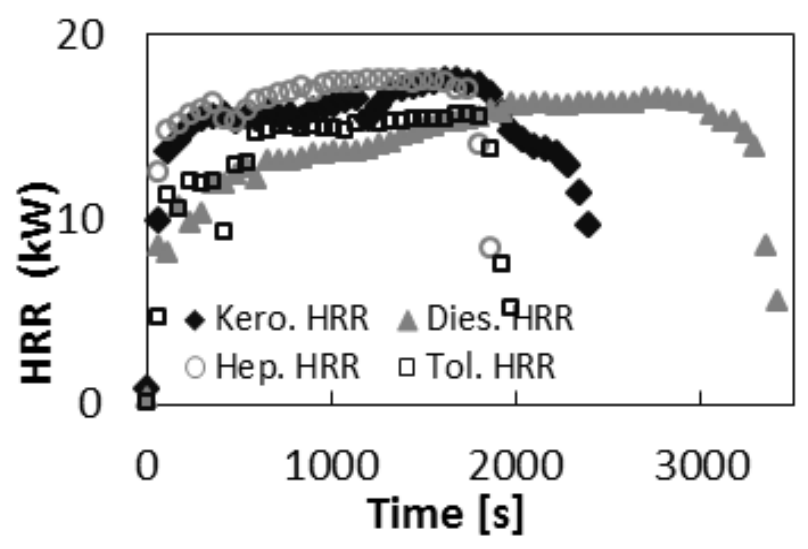

Fig. 2 Heat release rate as a function of time.

$35 \mathrm{~g}_{\mathrm{a}} / \mathrm{m}^{2}$. Utiskul et al [1] determined a fuel mass loss rate that converts to $170 \mathrm{~kW} / \mathrm{m}^{2}$, which is significantly higher than in the present work with larger pool size. However, the main reason for this different is that the combustion efficiency was very poor and so the fuel mass loss rate is not the same as the fuel consumption rate, due to emissions of very high $\mathrm{CO}$ and UHC. For the much higher ventilation used in the large scale work of Chamberlain [2] the HRR was 0.8 and $1.1 \mathrm{MW} / \mathrm{m}^{2}$, a range that is similar the $0.17-1.3 \mathrm{MW} / \mathrm{m}^{2}$ in the $0.064 \mathrm{~m}^{3}$ compartment of Utiskul et al. [1] for a wide range of ventilations.

The rate of burning or the time to reach the peak HRR and the time to burn all the fuel is shown in Fig. 2 to be influenced by the fuel volatility. The time to reach the peak HRR was in the order heptane, kerosene, toluene and diesel showed the slowest flame development. This is roughly proportional to their volatility, although toluene was more volatile than kerosene. However, the lower stoichiometric A/F meant that more toluene had to vaporise for the same air flow to achieve the same global fire equivalence ratio.

\section{Global Fire Equivalence Ratio}

The global fire equivalence ratio, $\varnothing$, was determined by carbon balance from the $\mathrm{CO}_{2}, \mathrm{CO}$ and total $\mathrm{HC}$ emissions from the ceiling layer mixed mean composition at the chimney exit. The results are shown in Fig. 3 for all four fuels as a function of time. These results were unexpected as there was no correlation with fuel volatility. Kerosene formed the richest global equivalence ratio and toluene and diesel were lean for most of the fire, although diesel was stoichiometric by the end phase of the fire. Heptane formed rich mixtures, but to a lesser extent than kerosene. Heptane and toluene also showed fluctuations in equivalence ratio which could be caused by the unstable ghosting flames. Diesel is the least volatile and would require a higher fire temperature to vaporize more fuel to produce rich mixtures. The diesel $\varnothing$ and toluene $\varnothing$ were similar and lean and kerosene and heptane were both rich for the same air flow.

The oxygen consumption HRR, shown as a function of time in Fig. 2, is shown as a function of $\varnothing$ in Fig. 4. The HRR increased with $\varnothing$ for all four fuels with a maximum close to stoichiometric conditions, richer mixtures for peak HRR for kerosene was due to the poor combustion efficiency for the rich mixtures in Fig. 4. Fig. 2 shows that there were two occasions in the fire when a given $\varnothing$ occurs, the initial phase of the fire when the pool was heating up and the final phase of the fire when the pool was running out of fuel. Thus when any parameter from the fire is plotted as a function of $\varnothing$ there are two values of the parameter for each $\varnothing$. This shows that the fire behave differently in the cold start phase of the fire than it does in the hot final fuel burn out phase. This behavior is shown in Fig. 4 for HRR and is seen later for the gaseous emissions and ceiling temperatures. The maximum $\varnothing$ was 0.9 for toluene, 1.1 for diesel, 1.2 for heptane and 1.8 for kerosene. There was no relationship in this order with fuel volatility.

\section{Fuel Mass Loss Rate}

The A/F by mass was determined from the exit duct gas sample composition using a carbon balance [17] and the fuel mass consumption rate was determined as the air mass flow rate divided by the A/F. The fuel mass flow rate derived in this way is shown in Fig. 5 for the four fuels tested. An alternative method to determine the fuel consumption is to take the measured HRR by oxygen consumption and divide by the combustion efficiency and the $\mathrm{CV}$. The combustion inefficiency is derived later from the gas analysis and it 


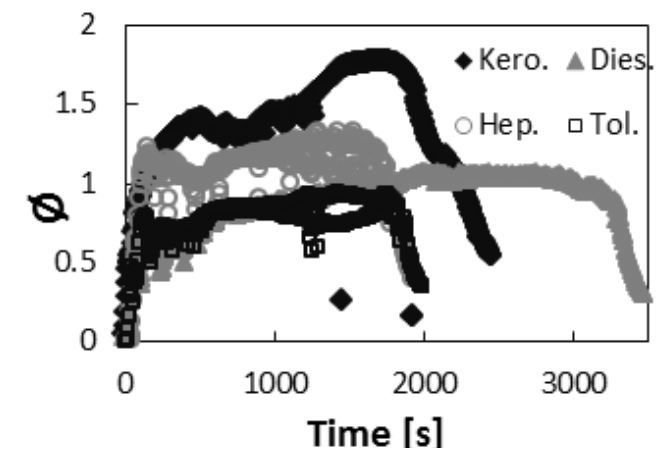

Fig. 3. $\varnothing$ as a function of time for the four pool fires.

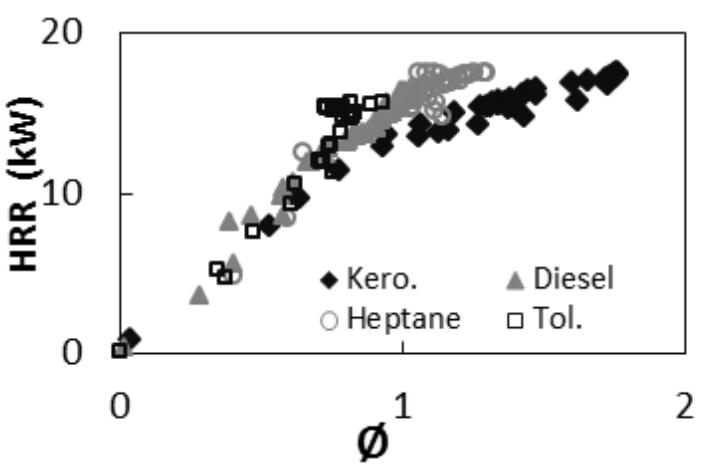

Fig. 4. HRR as a function of equivalence ratio

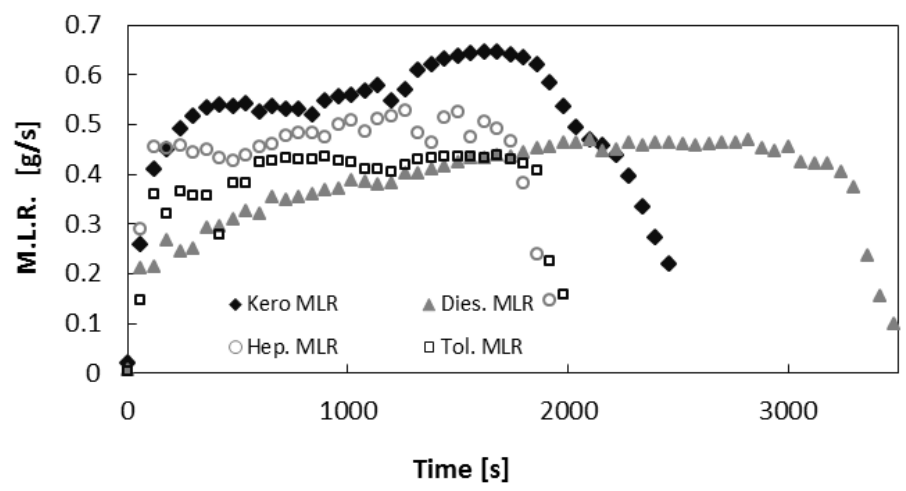

Fig. 5. Mass Loss Rate $\mathrm{g} / \mathrm{s}$ as a function of time for the four fuels.

is the energy not released from the consumption of the fuel. These procedures are detailed by Aljumaiah et al. [20], who investigated ventilation controlled pine wood crib fires in the present test facility for 5-37 $\mathrm{ACH}$ ventilation rates, where load cells recorded the actual mass. The HRR derived by oxygen consumption and that based on the measured fuel consumption rate multiplied by the combustion efficiency and the CV were in good agreement for the pine cribs [20]. These load cells had insufficient capacity to be used in the present work due to the weight of the large fuel tray and the $2.4 \mathrm{~kg}$ of fuel used.

For the peak diesel HRR of $16.5 \mathrm{~kW}$ the combustion efficiency was 0.77 and with a $\mathrm{CV}$ of $43 \mathrm{MJ} / \mathrm{kg}$ the fuel mass loss rate would be $0.5 \mathrm{~g} / \mathrm{s}$ and Fig. 5 shows that this is in approximate agreement with the measurements. This MLR converts to $3.1 \mathrm{~g}_{\mathrm{f}} / \mathrm{m}^{2} \mathrm{~s}$ and the range of peak MLR in Fig. 5 was $0.45-0.65 \mathrm{~g}_{\mathrm{f}} / \mathrm{s}$ or $2.8-4.1 \mathrm{~g}_{\mathrm{f}} / \mathrm{m}^{2} \mathrm{~s}$. The lowest MLR was for diesel and toluene and the highest was kerosene with heptane in between at $3.1 \mathrm{~g}_{\mathrm{f}} / \mathrm{m}^{2} \mathrm{~s}$. These mass loss rates were similar to that reported by Utisul et al. [1] for heptane for the same ventilation of $35 \mathrm{~g}_{\mathrm{a}} / \mathrm{m}^{2} \mathrm{~s}$, where the heptane mass loss was $4 \mathrm{~g}_{\mathrm{f}} / \mathrm{m}^{2} \mathrm{~s}$ for a $190 \mathrm{~mm}$ pool diameter. However, they were much lower than the freely ventilated MLR found by Chatris [3] for diesel of $55 \mathrm{~g}_{\mathrm{f} / \mathrm{m}^{2} \mathrm{~s}}$ for a $4 \mathrm{~m}$ diameter pool and for the two ventilation rates studied by Chamberlain [2], which for diesel gave MLR of $19-26 \mathrm{~g}_{\mathrm{f}} / \mathrm{m}^{2} \mathrm{~s}$, for large pool fires in a $96 \mathrm{~m}^{3}$ compartment with fire temperatures of $1000^{\circ} \mathrm{C}$ at the highest ventilation.

\section{Mean Ceiling Temperatures and Evidence for Ghosting Flames}

The average upper layer temperature measurements are shown in Fig. 6 as a function of time and in Fig. 7 as a function of equivalence ratio. Fig. 6 shows a similar temperature history for all four fuels. Fig. 7 shows that the fires moved quickly to near stoichiometric global fire equivalence ratios and then increased the temperature close to stoichiometric, as the chamber walls heated up. Fig. 6 also shows that the fuel burning times varied between the fuels, even though the initial mass of fuel and the air flow rate were the same. The time to burn the fuel was less than 2000 seconds for the Toluene and Heptane tests, while the Diesel test had the longest duration stretching to almost 3500 seconds. 


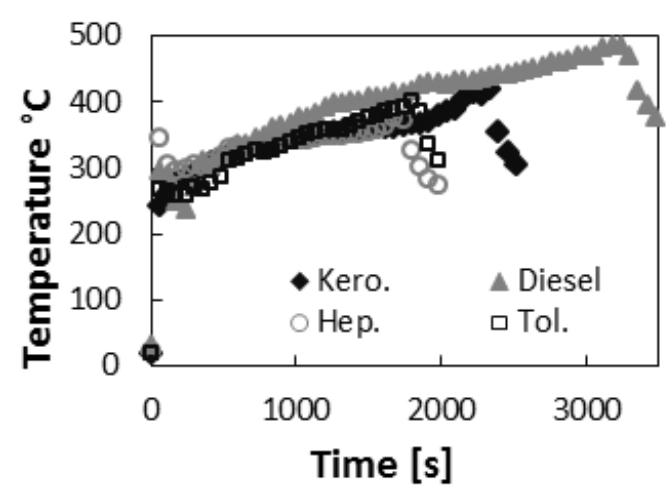

Fig. 6. Average upper layer temperatures as a function of time

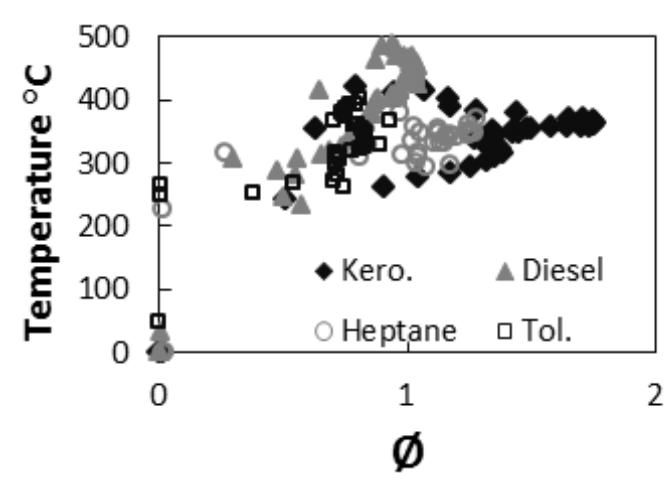

Fig. 7. Fire ceiling mean temperature as a function of the fire global equivalence rato

For all the fuels Fig. 7 shows that the peak temperature occurred in the latter stages of the fire as $\varnothing$ passed through stoichiometric just prior to the pool fire completing combustion of the fuel. This was a hotter period than during the cold start phase of the fire where stoichiometric conditions were also reached. The difference between the mean ceiling temperature at the cold start and hot end phase of the fires for $\emptyset=1$ was $150^{\circ} \mathrm{C}$ for kerosene, $80^{\circ} \mathrm{C}$ for diesel and $50^{\circ} \mathrm{C}$ for hexane. Toluene only just reached $\emptyset=1$ at the end of the test and this was the hottest condition. These temperature differences at $\varnothing=1$ were due to the differences in combustion efficiency.

Fig. 8a shows the temperature measurements for the Heptane fire $40 \mathrm{~cm}$ above the surface of the pool (Mid) and $30 \mathrm{~cm}$ above the ventilation slot at the rear of the compartment (Rear). It shows a high peak temperature above the pool at the beginning of the fire followed by a drop in temperature then a steady slow increase over the course of the burning which corresponds with the mean ceiling temperature increase. At the same time, the rear temperature readings (above the ventilation slot) showed a slower increase at the beginning of the tests, due to this region being locally lean as it is above the air inlet. This was followed by an increase in temperature which marks the transition to ghosting flames that stabilized at the ventilation slots rather than the fuel surface. This interpretation was confirmed by visual observations through the high temperature window. The Diesel pool fire temperatures in Fig. $8 \mathrm{~b}$ show a similar phenomenon to that of the heptane fire occurs but much later in the fire.

All four fuels showed a similar ghosting flame phenomena and the results are summarised in Table 2. This shows that the ceiling temperature at which ghosting flames first occurred increased as the fuel boiling point increased and the fire duration decreased as the boiling point decreased. As expected ghosting flames occur more readily for the more volatile fuels. However, once the compartment temperature is above the boiling point of the fuel they can occur in any fuel. The oscillations in $\varnothing$ in Fig. 3 for hexane and toluene were due to ghosting flame movement. As the flame leaves the pool to burn near the inlet air the pool cools and reduces vapour production. This results in the flame moving back from the air inlet to the pool and then the cycle repeats.

\section{Oxygen Concentration in the Pool Fires}

The oxygen concentrations in the fire ceiling gases are shown in Fig. 9a as a function of time and in Fig. 9b as a function of the global fire equivalence ratio. These results show that the oxygen level never reached zero for any of the fuels. Also, where rich equivalence ratios were found the oxygen was still not zero. The reason for this was the combustion inefficiency and the associated high $\mathrm{CO}$ and $\mathrm{HC}$ levels. The slower development of the diesel fire relative to kerosene is clearly seen in Fig. 9a, which is a reflection of the slower development of the HRR shown in Fig. 2.

\section{CO and HC Yields}

The yields of $\mathrm{CO}$ are shown as a function of time and equivalence ratio in Fig. 10. The equivalence ratio plots show an increase in yield as the fire becomes hotter and richer and then a decrease as the fire moves to extinction with increase in oxygen levels. Both yields were very high for lean and rich mixtures for all the fuels. For lean mixtures the high yields were due to low temperature combustion, for rich mixtures the 
(a)

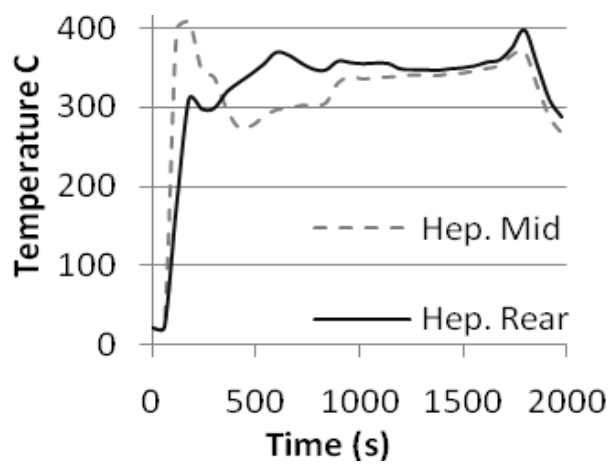

(b

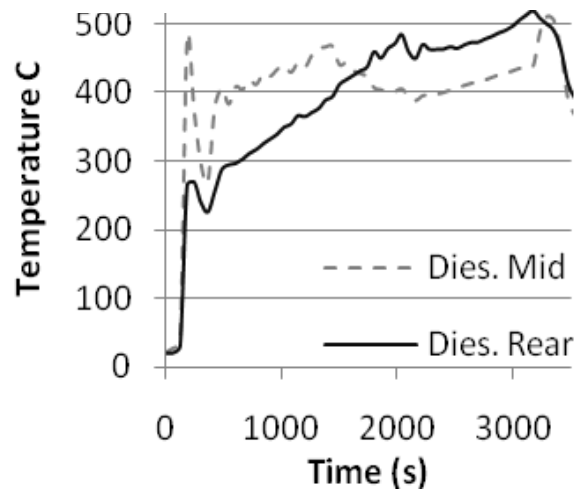

Fig. 8. Temperatures above the pool surface and at the rear vent for Heptane (a) and Diesel (b) .

Table 2. Summary of the conditions and time for the onset of ghosting combustion.

\begin{tabular}{|l|c|c|c|c|c|c|}
\hline & $\begin{array}{c}\text { Boiling } \\
\text { Temp.C }\end{array}$ & $\begin{array}{c}\mathrm{LHV} \\
\mathrm{kJ} / \mathrm{kg}\end{array}$ & $\begin{array}{c}\mathrm{CV} \\
\mathrm{MJ} / \mathrm{kg}\end{array}$ & $\begin{array}{c}\text { Start of } \\
\text { Ghosting } \\
\text { Flames s }\end{array}$ & $\begin{array}{c}\text { Start of } \\
\text { Ghosting } \\
\text { Temp. oC }\end{array}$ & $\begin{array}{c}\text { Fire } \\
\text { Duration } \\
\mathrm{s}\end{array}$ \\
\hline Heptane & 98.4 & 317 & 44.6 & 320 & 320 & 1880 \\
\hline Toluene & 110.4 & 360 & 40.5 & 360 & 290 & 1970 \\
\hline Kerosene & $150-260$ & 256 & 43.1 & 480 & 350 & 2420 \\
\hline Diesel & $160-360$ & 228 & 43.2 & 1680 & 430 & 3500 \\
\hline
\end{tabular}

a

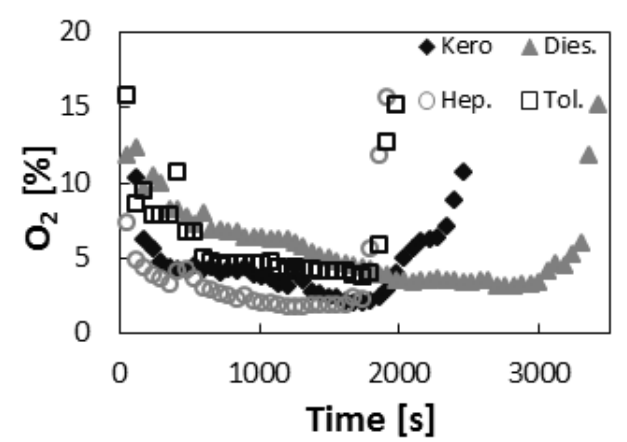

b

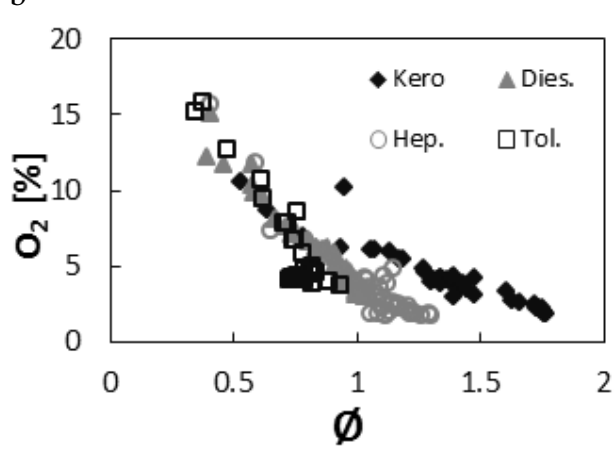

Fig. 9. Oxygen concentration as a function of time (a) and equivalence ratio (b).
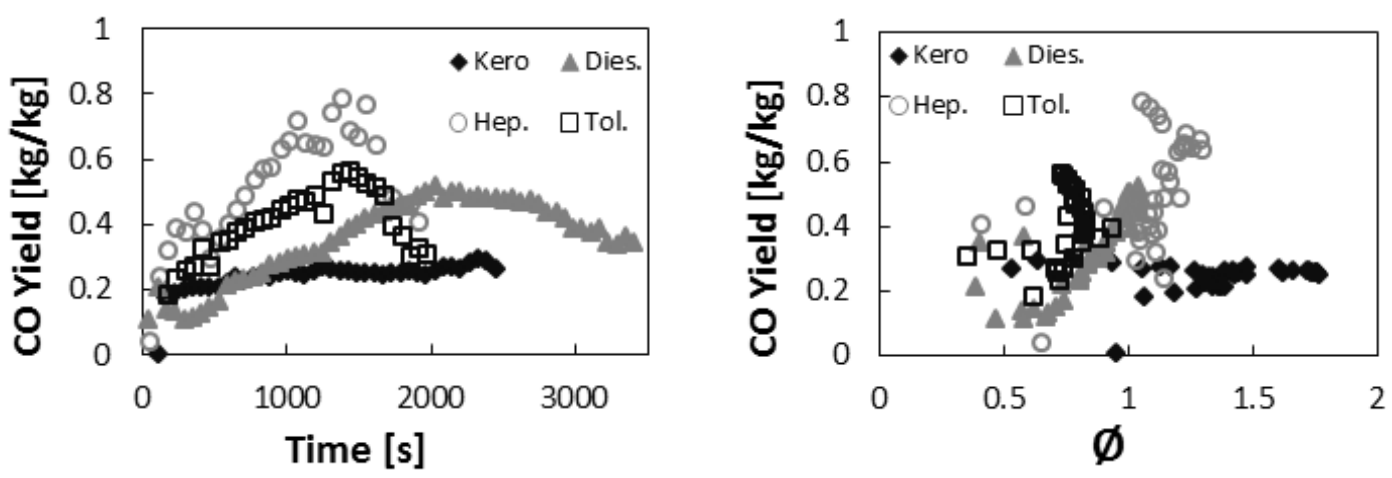

Fig. 10. $\mathrm{CO}$ yields as a function of time and global fire equivalence ratio 

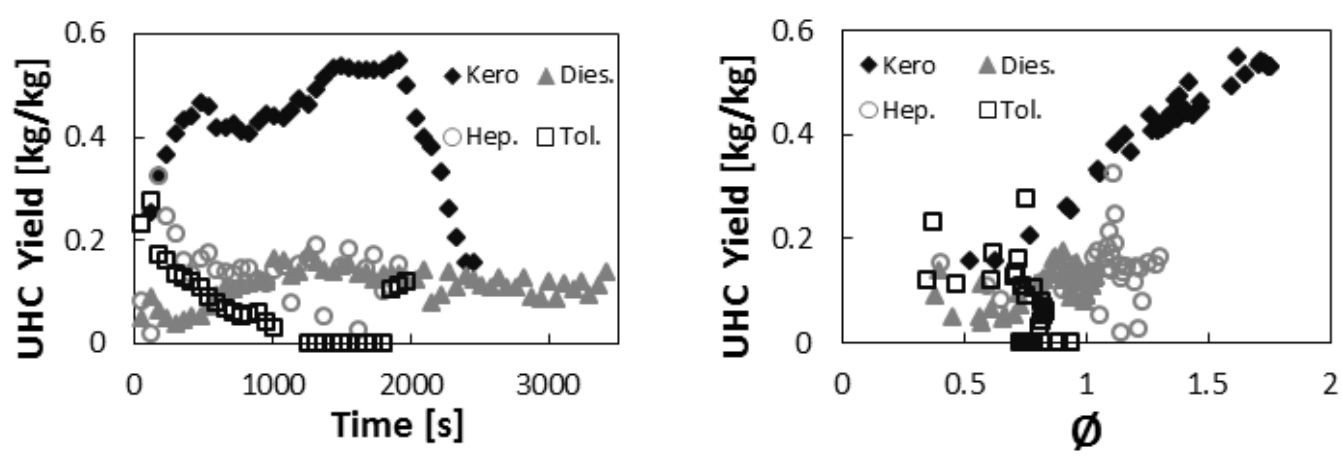

Fig. 11. HC yields as a function of time and global fire equivalence ratio.

high yields of $\mathrm{CO}$ were due to equilibrium $\mathrm{CO}$ as well as low temperature inefficient combustion $\mathrm{CO}$. There would also be high levels of hydrogen associated with the rich mixtures, which are calculated assuming water gas equilibrium in the Spindt [17] equation used for the computation of equivalence ratio. The peak yield of CO for heptane was $75 \%$ and this is vastly greater than the $1 \% \mathrm{CO}$ yield measured by Tewarson [21] for over ventilated heptane fires. Bundy et al. [5] found CO yields for heptane pool fires varied from 2 to $30 \%$ depending on $\varnothing$. This is in agreement with Tewarson's [21] work on CO yield v $\varnothing$.

The peak yields of $\mathrm{CO}$ were inversely related to the fuel volatility for the two single component fuels, with the $75 \%$ for heptane reduced to 55\% for toluene. For toluene Bundy et al. [5] found CO yields from 2\% $6 \%$ for $\varnothing$ from 0.6 to 1.3 . These yields [5] were much lower than in the present work due to the higher fire temperatures. In this work kerosene had a peak $\mathrm{CO}$ yield of $25 \%$, whereas for diesel it was $50 \%$. This was mainly associated with difference in $\varnothing$ at the peak yield. Aljumaiah et al. [20] have reported CO emissions for pine wood cribs in the same test facility as the present work and with the same air ventilation. They found CO yields peaked at 14\%, much lower than the levels found in the present work for pool fires. The peak fire temperature was $450^{\circ} \mathrm{C}$ for the pine wood fires, similar to that for diesel in this work. The lower $\mathrm{CO}$ values are considered to be due to the oxygenated fuel with pine wood, which increases $\mathrm{CO}$ oxidation so that combustion efficiency( $>80 \%)$ generated $\mathrm{CO}$ was lower.

The high yields of $\mathrm{HC}$ are shown in Fig. 11 and were due to low temperature inefficient combustion. For kerosene $40-50 \%$ of the fuel was vaporized and not burned due to the lack of oxygen with $\emptyset>1$ for most of the fire. This led to ghosting combustion with the flame stabilized around the air inlets at the side of the chamber. Diesel was much less volatile and only $10-15 \%$ of the fuel was in unburned vapour form and $\varnothing<1$ for most of the fire. Heat from the fire was vaporizing kerosene that was not burning. The higher final boiling point for diesel led to much lower hydrocarbon levels due to less vaporisation and leaner $\emptyset$. For the more volatile single component fuels the fire vaporised the fuels earlier in the fire, there were significant differences between heptane and toluene. Toluene produced lean $\varnothing$ with very low UHC during the hottest part of the fire and heptane produced rich $\varnothing$ with very high CO and peak UHC at $15 \%$. There were very similar fire temperatures for the two fuels and the difference in boiling points was only $12^{\circ} \mathrm{C}$.

Associated with the high yields of $\mathrm{CO}$ and $\mathrm{HC}$ were very high toxicity levels. CO toxicity for LC50 is 3,000 ppm and peak levels in the fire were between 7 and 17 times this critical toxicity level for all four fuels. CO was highest for heptane and lowest for toluene, with kerosene less than diesel as shown in Fig. 10. Hydrocarbon levels were also very high for all fuels, with kerosene much higher than for the other fuels, as shown in Fig. 11. This was mainly due to the much richer mixtures that occurred with kerosene as shown in Fig. 11. Within these high hydrocarbon levels were many toxic hydrocarbons such as benzene. The low temperature combustion also gave rise to large concentrations of toxic aldehydes including acrolein and formaldehyde.

\section{Combustion Efficiency}

The combustion efficiency results are shown in Fig. 12 and these were very low, particularly for kerosene fires. A feature of the low combustion efficiency in these fires is that there is oxygen present during rich combustion, as shown in Fig. 9 for all the fuels tested. This was a result of the poor combustion efficiency 


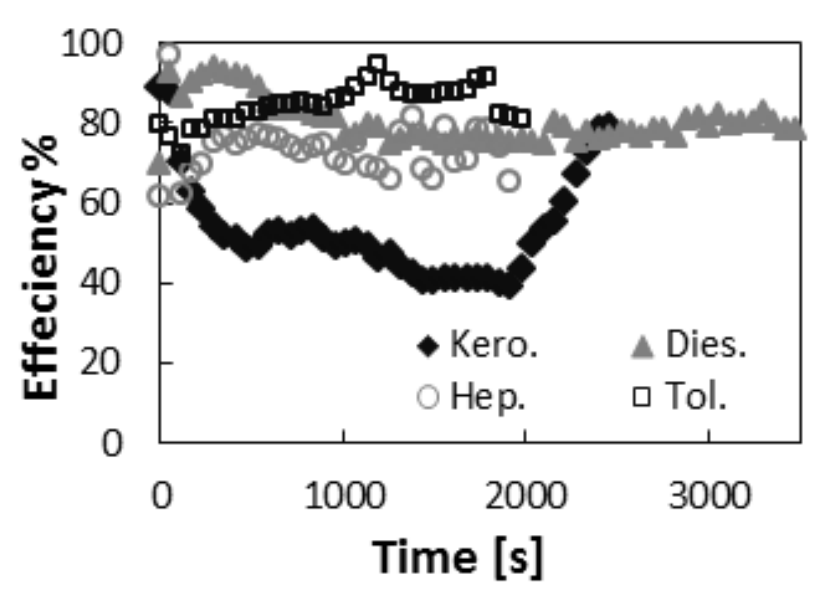

Fig. 12. Combustion efficiency as a function of time.

Table 3 Comparison of the Fire Conditions at the Peak HRR for Pool and Pine Crib Fires [20] at 10.6 ACH

\begin{tabular}{|l|c|c|c|c|c|c|c|c|}
\hline Fuel & $\begin{array}{c}\text { Peak } \\
\text { HRR } \\
\mathrm{kW}\end{array}$ & $\begin{array}{c}\text { Time to } \\
\text { peak HRR }\end{array}$ & $\varnothing$ & $\begin{array}{c}\text { Temp } \\
{ }^{\circ} \mathrm{C}\end{array}$ & $\begin{array}{c}\mathrm{O}_{2} \\
\%\end{array}$ & $\begin{array}{c}\mathrm{CO} \\
\text { Yield g/kg }\end{array}$ & $\begin{array}{c}\text { UHC } \\
\text { Yield g/kg }\end{array}$ & $\begin{array}{c}\text { Comb. } \\
\text { Eff. \% }\end{array}$ \\
\hline $\begin{array}{l}\text { Diesel } \\
\text { Pool }\end{array}$ & 16.5 & $2000 \mathrm{~s}$ & 1.05 & 480 & 3 & 500 & 150 & 75 \\
\hline $\begin{array}{l}\text { Kerosene } \\
\text { Pool }\end{array}$ & 17.5 & $1500 \mathrm{~s}$ & 1.7 & 420 & 2 & 750 & 530 & 40 \\
\hline $\begin{array}{l}\text { Pine } \\
\text { Crib [20] }\end{array}$ & 15 & $1400 \mathrm{~s}$ & 1.8 & 450 & 5.5 & 120 & 50 & 80 \\
\hline
\end{tabular}

which indicates that all the fuel had not reacted with the oxygen, even though the overall mixture was rich. Thus, the combustion in these air starved fires was well removed from equilibrium conditions, as there are no hydrocarbons at equilibrium. The lack of measurements of UHC in compartment fires also means that there are few measurements of compartment fires combustion efficiency.

\section{Comparison with Pine Wood Crib Fires for the Same Ventilation [20]}

Pine wood crib fires have been investigated by Aljumaiah [20] at the same air ventilation rate in the present fire compartment as in this experimental fire compartment. The $4.8 \mathrm{~kg}$ fire load had a very similar energy content of $90 \mathrm{MJ}$ to that in the present work (100 MJ) when the difference in CV is taken into account. Some of the peak values of key parameters are compared in Table 3. This shows that the peak HRR were similar, which illustrates that this is controlled by the ventilation and not by the fuel. The differences in HRR were mainly related to differences in the combustion efficiency. The peak temperatures were similar. The pine crib was the fastest to reach the peak HRR, but similar to heptane pool fires. The reason for the fast flame propagation in pine cribs was the larger surface area than for the pool fires and hence the greater rate of release of volatiles. Also, the crib was of significant height and the top of the crib was exposed to hotter gases than the pool. Comparison is made in Table 3 with the $\mathrm{CO}$ and UHC yields $(\mathrm{g} / \mathrm{kg}$ fuel) for pine crib fires [20].This shows that the present hydrocarbon pool fires have much higher CO and UHC yields than for pine wood cribs. The oxygenated composition of wood makes $\mathrm{HC}$ and $\mathrm{CO}$ oxidation quicker for the same temperature and this was the reason for the lower $\mathrm{CO}$ and HC. These results show that the toxic hazards associated with pool fires in compartments is worse than for pine fires for the same ventilation.

\section{Particulate Yields and Composition}

Each heated particulate filter paper sample involved about a five minute sample period and then a short period to change the filter paper. Sufficient filters were obtained to enable the time variation of the 
a)

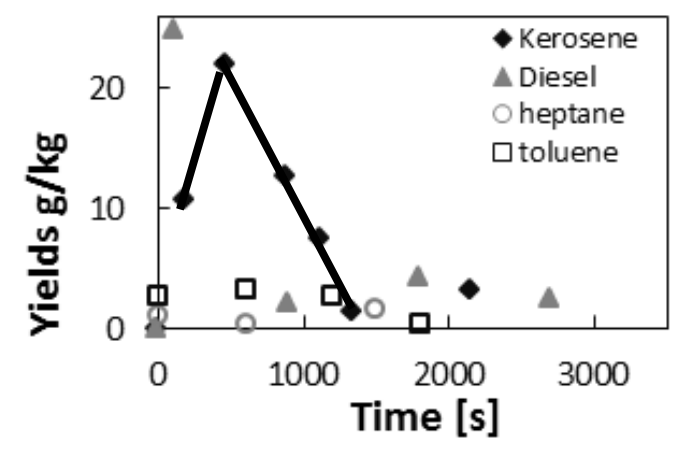

(b)

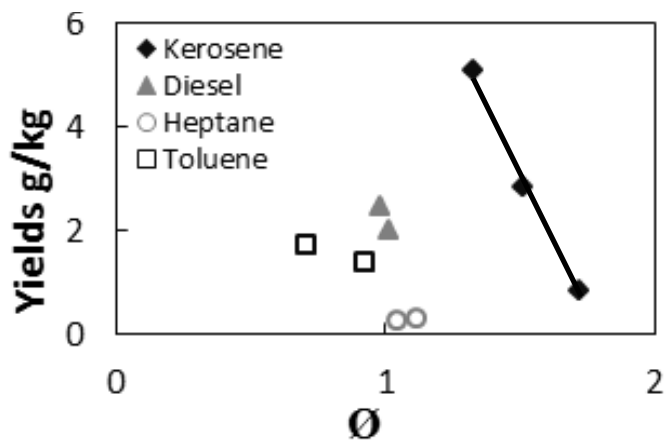

Fig. 13. Particulates yields ( $\mathrm{g} / \mathrm{kg}$ ) as a function of time (a) and carbon yield as a function of $\emptyset$ (b).

Table 4. Thermal Gravimetric Analysis (TGA) of Particle Filters.

\begin{tabular}{|c|c|c|c|c|c|c|}
\hline Fuel & $\begin{array}{c}\text { Time } \\
\mathrm{s}\end{array}$ & $\begin{array}{c}\text { Particulate } \\
\mathrm{g} / \mathrm{kg}\end{array}$ & $\begin{array}{c}\text { Carbon } \\
\mathrm{g} / \mathrm{kg}\end{array}$ & $\begin{array}{c}\text { Volatile } \\
\mathrm{g} / \mathrm{kg}\end{array}$ & Carbon $\%$ & Volatile \% \\
\hline Heptane & 300 & 0.9 & 0.20 & 0.70 & 22 & 78 \\
& 1800 & 0.9 & 0.25 & 0.65 & 29 & 71 \\
\hline Toluene & 300 & 1.6 & 1.0 & 0.6 & 63 & 37 \\
& 1800 & 1.75 & 1.06 & 0.69 & 60 & 40 \\
\hline Kerosene & 300 & 6.53 & 4.73 & 1.8 & 72 & 28 \\
& 1200 & 5.67 & 3.10 & 2.57 & 55 & 45 \\
& 1800 & 2.46 & 1.09 & 1.37 & 44 & 56 \\
\hline Diesel & 1800 & 3.15 & 1.83 & 1.32 & 58 & 42 \\
& 2900 & 3.01 & 1.54 & 1.45 & 50 & 50 \\
\hline
\end{tabular}

particulate yields to be determined. The $\mathrm{A} / \mathrm{F}$ by mass required for the conversion of the particle concentration to yield in Eq. 1 was taken as the mean A/F during the sample period. The particulate yields are shown in Fig. 13a as a function time. The particulate yields were unexpectedly low for rich mixtures and the highest value was $2.5 \%$ for diesel and $2.2 \%$ for kerosene. These peak yields occurred in the early stages of the fire when $\varnothing$ was 1.3 for kerosene and 0.7 for diesel. For toluene $\emptyset$ was always lean at $0.7-0.8$ and for heptane $\varnothing$ was $1-1.2$ for all the particulate filter measurements. Particulate yields for heptane and toluene were very low at $<0.2 \%$ and $<0.4 \%$ respectively.

The filter papers were analysed by TGA to determine the volatile and soot fractions of the particulate. The filter paper was heated in nitrogen up to $600^{\circ} \mathrm{C}$ and the weight loss was determined, the nitrogen was then switched off and air was added and this resulted in the carbon oxidizing and the weight loss was the carbon fraction. Any weight remaining was the ash fraction, which was negligible in the present work. The results are summarized in Table 4 which shows that the volatile fraction was high for all the fuels used in the pool fires. This was due to the very high UHC emissions shown in Fig.11. The heptane particulates were dominated by the volatile fraction and in contrast toluene particulates were dominated by carbon, as expected from the higher soot forming tendency of aromatic compounds. For kerosene and diesel pool fires the carbon and volatile fractions were of near equal importance.

The carbon yields have been plotted as a function of $\varnothing$ in Fig. $13 \mathrm{~b}$ and were below $0.3 \%$ for all fuels except for one of the kerosene particulate samples. These low carbon yields were low due to low temperature rich combustion, which is a known low soot operational regime. It is known as low temperature combustion (LTC) in diesel engines and is used to achieve low soot emissions at low power low temperature engine conditions $[22,23]$. The three kerosene samples showed the reduction in soot that occurs as the mixtures becomes richer due to the reduced temperatures and low oxygen concentrations $[22,23]$. For the other fuels the samples were close to $\varnothing \sim 1$ and the ranking of the fuels for soot yields was as expected, with the pure $\mathrm{n}$-alkane heptane carbon yield at $0.03 \%$. and toluene higher at $0.15 \%$, as expected for a pure aromatic fuel. 
This heptane carbon yield value is a factor of 10 lower than the 3.7\% reported by Tewarson [21] for over ventilated conditions. Tewarson [21] also found for under ventilated rich conditions that soot increased relative to over ventilated conditions by a factor of 2 at $\varnothing \sim 4$, but this would only happen if the fire temperatures were substantially higher than in the present work. For real fuels with a range of n-alkanes and aromatic compounds diesel had a higher soot yield, at $0.2 \%$, than toluene at $0.15 \%$. However, the highest carbon emissions were for kerosene, although a sample at $\varnothing \sim 1$ was not analysed, but extrapolation of the results in Fig. 13b would indicate that the carbon yield would be about $1 \%$. The carbon yields of Chamberlain [2,9] for diesel pool fires were much higher due to the high combustion temperatures with the higher ventilation of their fires. The carbon yields of Bundy et al. [5] for heptane were $4 \%-38 \%$ for $\varnothing$ from 0.6 to 3.5. For toluene the carbon yields were $14 \%-28 \%$ for $\varnothing$ from $0.06-1.3$. For $\emptyset=1$ the toluene yield was $18 \%$ compared with $8 \%$ for heptane and in the present work was $0.1 \%$ and $0.02 \%$ respectively and the difference was due to the $1150^{\circ} \mathrm{C}$ temperature of their well ventilated comparment pool fires. This shows that rich combustion requires high fire temperatures to generate high yields of soot.

\section{CONCLUSIONS}

1. Pool fires in air starved compartment fire conditions have ghosting flames which detach from the surface of the pool and burn closer to the inlet air ports. The ceiling temperature at which ghosting flames first occurred increased as the fuel boiling point increased and the fire duration decreased as the boiling point decreased.As expected ghosting flames occur more readily for the more volatile fuels. However, once the compartment temperature is above the boiling point of the fuel they can occur in any fuel.

2. All four pool fires had a similar peak HRR in the range $16-18 \mathrm{~kW}$ or $100-112 \mathrm{~kW} / \mathrm{m}^{2}$. This is that expected from the air flow, as there is typically $3 \mathrm{MJ} / \mathrm{kg}$ of air released in combustion [19], irrespective of the fuel and for $0.0056 \mathrm{~kg} / \mathrm{s}$ of air supply to the compartment $16.8 \mathrm{~kW}$ HRR would be expected,

3. The pool fires all had relatively low ceiling temperatures in the range $300-500^{\circ} \mathrm{C}$, with very poor combustion efficiency and very high yields of $\mathrm{CO}$ and $\mathrm{HC}$, with associated high toxicity levels.

4. Kerosene formed the richest global equivalence ratio and toluene and diesel were lean for most of the fire, although diesel was stoichiometric by the end phase of the fire. Heptane formed rich mixtures, but to a lesser extent than kerosene.

5. The peak yield of CO was between 10 and $75 \%$ of the fuel consumed depending on the fuel. For heptane it was $75 \%$ and this is vastly greater than the $1 \% \mathrm{CO}$ yield measured by Tewarson [21] for over ventilated heptane fires. Kerosene had a peak CO yield of $25 \%$, whereas for diesel it was $50 \%$. This was mainly associated with differences in $\varnothing$ at the peak yield

6. Toluene produced lean $\varnothing$ with very low UHC during the hottest part of the fire and heptane produced rich $\varnothing$ with very high CO and peak UHC at $15 \%$. For kerosene $40-50 \%$ of the fuel was vaporized and not burned due to the lack of oxygen with $\emptyset>1$ for most of the fire. Diesel was much less volatile and only $10-15 \%$ of the fuel was in vapour form unburned and $\varnothing<1$ for most of the fire.

7. The rich low temperature fire conditions produced relatively low particulate and carbon yields, compared with over ventilated fires. There was a very large volatile fraction of the particulate emissions and only for Toluene was carbon greater than $50 \%$ of the particulate mass.

\section{ACKNOWLEDGEMENTS}

Omar Aljumaiah would like to than the Saudi Government for a research scholarship. Thanks to Bob Boreham who operated and maintained the test equipment. The fire compartment test facility was constructed with a grant from the University of Leeds.

\section{REFERENCES}

1. Utiskul, Y., Quintiere, J.G., Rangwala, A.S., Ringwelski, B.A., Wakatsuki, K. and Naruse, T., (2005) Compartment fire phenomena under limited ventilation, Fire Safety J., 40: 367-390.

Doi:10.1016/j.firesaf.2005.02.002

2. Chamberlain, G.A., (1966), The Hazards posed by large scale pool fires in offshore platforms, Trans. I.ChemE., 74: Part B., 81-87.

3. Chartris, J.M., Quintela, J., Folch, J., Planas, E., Arnaldos, J. and Casal, J., (2001) Experimental Study of Burning Rate in Hydrocarbon Pool Fires . Combustion and Flame, 126: 1373-1383. 
4. Ko, G.H., Hamins, A., Bundy, M., Johnsson, E.I., Kim, S.C. and Lenhert, D.B., (2009) Mixture Fraction Analysis of Combustion Products in the Upper Layer of Reduced Scale Compartment Fires, Combustion and Flame, 156:467-476. Doi:10.1016/j.combustflame.2008.08.012

5. Bundy, M., Hamins, A., Johnsson, E.I., Kim, S.C., Ko, G.H. and Lenhert, D.B., (2007) Measurements of Heat and Combustion Products in Reduced-Scale Ventilation-Limited Compartment Fires. NIST Technical Note 1483.

6. Gottuck, D.T., Roby, R.J. and Beyler, C.L., (1992) A Study of Carbon Monoxide and Smoke Yields from Compartment Fires with External Burning. Twenty Fourth Symposium (International) Combustion, The Combustion Institute, 1799-1735.

7. Andrews, G.E., Ledger, J. and Phylaktou, H.N|., Enclosed pool fire flame temperatures and global heat loss using gas analysis', Fire Safety Science - Proceedings of the Sixth International Symposium, International Association for Fire Safety Science, 1999, pp.591-602.

8. Andrews, G.E., Ledger, J. and Phylaktou, H.N., Pool fires in a low ventilation enclosure, I.Chem.E. Symposium on Hazards XV, IChemE Symposium Series No. 147, 2000, p.147-183.

9. Andrews, G.E., Ledger, J. and Phylaktou, H.N., The Gravimetric Determination of Soot Yields in Enclosed Pool Fires, Fire and Explosion Hazards - Proceedings of the Third International Seminar, Windermere, 2000, pp. 121-136.

10. BS 5588.Part 4 (1998), Fire Precautions in the design, construction and use of buildings. Code of Practice for smoke control using pressure differentials.

11. Sugawa, O., Kawagoe, K. and Oka, Y., (1989) Burning behavior in a poor-ventilation compartment fire - Ghosting fire'. Fire Science and Technology 9(2) pp. 5-14.

12. Peatross, M.J. and Beyler, C.I., Thermal environment prediction in steel bounded preflashover compartment fires, Fire Safety Science - Proceedings of the Fifth International Symposium, International Association for Fire Safety Science, 1997, p. 415-426.

13. Audounin, I., Such, J.M., Malet, J.C. and Casselmann, C., A real scenario for a Ghosting flame, Fire Safety Science - Proceedings of the Fifth International Symposium, International Association for Fire Safety Science, 1997, .pp. 1261-1272, 1997.

14. Wieczorek, C.K., Vandsburger, U., Lattimmer, B. and McKay, C. (1999) "The Applicability of Correlations Between the Species Formation and the Global Equivalence :Ratio in a $1 / 2$ Scaled ISO Compartment with Non-gaseous Fuel. Fire Safety Science Proc. Sixth International Symposium, pp.965-976. Poitier. International Association for Fire Safety Science

15. Cheung, S.C.P., Lo, S.M., Yeoh, G.H. and Yeon, R.K.K., (2006) The Influence of Gaps of Fireresisting Doors on the Smoke Spread in a Building Fire". Fire Safety J., 41:539-546. doi 10.1016/j.firesaf.2006.05.007

16. Aljumaiah, O., Phylaktou, H.N. Andrews, G.E., Heath, I.M.L, Ledger, J.S. Ghosting Flames in a Low Ventilation Compartment with Kerosene Pool Fires. Proc. of the International Congress "Combustion and Fire Dynamics", Santander, Spain, 2010. (CFD2010).

17. Spindt, R.S., “Air/Fuel Ratio from Exhaust Gas Analysis”. SAE Paper 650507, 1965.

18. Stec, A and Hull, R., Fire Toxicity, Woodhead Publishing and CRC Press, 2010.

19. Goodger, E.M. (1980), “Alternative Fuels”Macmillan Press, p.74-75.

20. Aljumaiah, O. Andrews, G.E., Mustafa, B. G., Al-Qattan, H., Shah, V. and Phylaktou H.N., "Air Starved Wood Crib Compartment Fire Heat Release and Toxic Gas Yields". Fire Safety ScienceProceedings of the Tenth International Symposium, pp. 1263-1276, 2011. International Association for Fire Safety Science / DOI: 10.3801/IAFSS.FSS.10-1263

21. Tewarson, A. (1995) "Generation of Heat and Chemical Compounds in Fires", Chapter 3-4 in SPFE Handbook of Fire Protection Engineering $2^{\text {nd }}$. Ed., Ed. P.J. DiNenno, Quincy, MA, NFPA. 
22. Ogawa, H., Miyamoto, N., Shimizu, H. And Kido, S., 'Characteristics of Diesel Combustion in Low Oxygen Mixtures with Ultra-High EGR'. SAE Paper 2006-01-1147, 2006.

23. Akihama, K., Takatori, Y., Inagaki, K., Saski, S. and Dean, A.M. (2001)"Mechanism of the Rich Diesel Combustion by Reducing Temperature". SAE Paper 2001-01-0655. DOI:10.4271/2001-010655. 